\title{
ANALISIS AKUNTANSI PERSEDIAAN BARANG PADA CV. ANUGRAH DJAM RITEL
}

\author{
Nur Aisyah \\ Sekolah Tinggi Ilmu Ekonomi Tri Dharma Nusantara Makassar
}

\begin{abstract}
The research aimed to know the suitability of inventory accounting applied to CV. Anugrah Djam Retail with inventory accounting of PSAK No.14 of 2014. The type of data used is qualitative and quantitative data. Data source used is primary data and secondary data. The method of analysis used is comparative descriptive method. The results showed that inventory accounting applied to CV. Anugrah Djam Ritel has been in accordance with the accounting of inventories of PSAK No.14 of 2014.
\end{abstract}

Keywords : $\quad$ Accounting Inventory

\begin{abstract}
ABSTRAK
Penelitian bertujuan untuk mengetahui kesesuaian akuntansi persediaan yang diterapkan pada CV. Anugrah Djam Ritel dengan akuntansi persediaan PSAK No.14 Tahun 2014. Jenis data yang digunakan adalah data kualitatif dan kuantitatif. Sumber data yang digunakan adalah data primer dan data sekunder. Metode analisis yang digunakan adalah metode deskriptif komparatif. Hasil penelitian menunjukkan bahwa akuntansi persediaan yang diterapkan pada CV. Anugrah Djam Ritel telah sesuai dengan akuntansi persediaan PSAK No.14 Tahun 2014.
\end{abstract}

Kata kunci : Akuntansi Persediaan Barang

\section{PENDAHULUAN}

\section{Latar Belakang}

Dalam melakukan kegiatan operasional perusahaannya tentu memiliki faktor-faktor pendukung agar kegiatan perusahaan dapat berjalan dengan lancar. Hal ini berlaku bagi semua jenis perusahaan, baik yang bergerak di bidang jasa, dagang maupun manufaktur perlu melakukan pencatatan akuntansi untuk mengetahui kondisi keuangan usahanya. Karena dari laporan keuangan yang dihasilkan akan dapat menunjukkan keadaan keuangan perusahaan yang sesungguhnya, apakah mengalami keuntungan ataupun sebaliknya. Proses transaksi perusahaan dagang hampir sama dengan perusahaan jasa, hanya saja dalam perusahaan dagang harus memperhitungkan harga pokok penjualan dalam pencatatan persediaan. Perhitungan harga pokok penjualan pada perusahaan dagang dilakukan pada saat terjadinya penjualan barang dagang, yang 
dalam hal ini mengakibatkan berkurangnya jumlah persediaan barang dagang yang dimiliki oleh perusahaan.

Persediaan merupakan unsur yang berperan penting didalam kegiatan perusahaan karena tanpa adanya persediaan, perusahaan tidak dapat menjual kembali barangnnya (untuk perusahaan dagang) dan tidak dapat melakukan kegiatan produksi (untuk perusahaan manufaktur). Ikatan Akuntan Indonesia menyatakan bahwa persediaan adalah aset yang tersedia untuk dijual dalam kegiatan usaha biasa, dalam proses produksi penjualan tersebut atau dalam bentuk bahan atau perlengkapan untuk digunakan dalam proses produksi atau pembelian jasa. Persediaan termasuk dalam kelompok aset lancar karena jika terjadi penjualan barang secara tunai maka jumlah kas yang dimiliki perusahaan akan bertambah. Tetapi jika penjualan barang dilakuan secara kredit maka perusahaan harus menunggu dalam tenggang waktu tertentu sampai dengan pembeli tersebut membayar hutangnya sehingga dapat menambah jumlah kas perusahaan.

Metode pencatatan dan penilaian persediaan yang diterapkan oleh perusahaan juga tidak semuanya sesuai dengan ketentuan yang berlaku, dalam hal ini mengacu pada Standar akuntansi keuangan yang berlaku di Indonesia. Pada Pernyataan Standar Akuntansi Keuangan (PSAK) No.14 dijelaskan tentang berbagai hal yang berhubungan dengan persediaan, diantaranya pengukuran persediaan, metode apa saja yang boleh digunakan dalam penilaian persediaan dan lain sebagainya. CV. Anugrah Djam Ritel adalah sebuah perusahaan yang bergerak di bidang perdagangan (swalayan) yang memiliki berbagai jenis barang untuk dijual. Salah satu produknya yaitu air mineral (AQUA). Aqua telah dikenal masyarakat luas sebagai salah satu produk air mineral di Indonesia. Meskipun banyak bermunculan produk air mineral baru, sebagian besar masyarakat masih tetap setia dengan produk ini.

Dari uraian diatas, maka dapat diketahui bahwa hal-hal yang berhubungan dengan persediaan sangat kompleks sehingga diperlukan pencatatan dan penilaian persediaan yang sesuai dengan standar akuntansi keuangan yang berlaku di Indonesia.

\section{Rumusan Masalah}

Berdasarkan latar belakang yang telah dikemukakan, maka yang menjadi rumusan masalah dalam penelitian ini 
adalah apakahakuntansi persediaan pada CV. Anugrah Djam Ritel Makassar telah sesuai dengan akuntansi persediaan PSAK No.14 tahun 2014.

\section{TINJAUAN PUSTAKA}

\section{Pengertian Persediaan}

Persediaan merupakan salah satu aktiva yang paling aktif dalam operasi kegiatan perusahaan dagang. Persediaan juga merupakan aktiva lancar terbesar dari perusahaan dagang maupun manufaktur. Pengaruh persediaan terhadap laba lebih mudah terlihat ketika kegiatan bisnis sedang berfluktuasi.

Persediaan merupakan salah satu elemen penting dalam menentukan hargapokok penjualan pada perusahaan dagang eceran maupun perusahaan dagang dalam partaibesar, persediaan barang dagang merupakan elemen penting dalam penentuan hargapokok pada perusahaan barang dagang. Secara umum istilah persediaan barang adalah barang-barang yang dimiliki untuk dijualkembali atau memproduksi barangbarang yang akan dijual. Istilah yangdigunakan untuk menunjukkan barang-barang yang dimiliki oleh suatu perusahaan akan tergantung pada jenis usaha perusahaan.
Untuk mengetahui kategori ke dalam persediaan, perlu diketahui terlebih dahulu apa sebenarnya definisi atau pengertian persediaan itu sendiri. Menurut Pernyataan Standar Akuntansi Keuangan (PSAK) No.14 revisi (2014;31) pengertian persediaan adalah asset:

1. Tersedia untuk dijual dalam kegiatan usaha biasa,

2. Dalam proses produksi untuk penjualan tersebut, dan

3. Dalam bentuk bahan atau perlengkapan (supplies) untuk digunakan dalam proses produksi atau pemberian jasa.

Persediaan pada umumnya dipisahkan berdasarkan pokok pikiran yang meliputi jenis barang yang cukup banyak dan merupakan bagian yang cukup berarti dari seluruh aktiva perusahaan. Disamping itu, transaksi yang berhubungan dengan persediaan merupakan aktivitas yang paling sering terjadi. Dalam laporan keuangan, persediaan merupakan hal yang sangat penting karena baik laporan laba rugi maupun neraca sebuah perusahaan dagang atau perusahaan industri, persediaan seringkali merupakan bagian yang terbesar dari keseluruhan aktiva lancar yang dimiliki perusahaan. 


\section{Jenis-Jenis Persediaan}

Jenis-jenis persediaan akan berbeda sesuai dengan bidang atau kegiatannormal usaha perusahaan tersebut. Berdasarkan bidang usaha perusahaan dapat terbentuk perusahaan industri (manufacture), perusahaan dagang, ataupun jasa.

Keown dkk (2010;312), untuk mengilustrasikan pemisahan fungsi dengan lebih baik maka dijelaskan beberapa tipe umum persediaan yaitu : persediaan bahan mentah, persediaan barang setengah jadi (work in proses), persediaab barang jadi. Sementara bagi perusahaan jasa, jenis persediaannya relatif tidak ada karena perusahaan jasa tidak menjual barang tetapi menjual/memberikan layanan atau jasa kepada orang yang membutuhkan perusahaan.

\section{Pernyataan Standar Akuntansi}

\section{Keuangan (PSAK) No.14 Tahun 2014}

PSAK adalah standar yang harus diikuti dalam pencatatan dan pelaporan akuntansi di Indonesia. PSAK ini merupakan aturan-aturan yang harus ditaati oleh para akuntan agar pelaporan akuntansi di Indonesia ini menjadi lebih efektif.

1. Persediaan
Dalam PSAK No.14 ini, Ikatan Akuntansi Indonesia mengkhususkan pernyataannya mengenai persediaan. Ini terdiri dari bagian pendahuluan, penjelasan dan pengungkapan mengenai persediaan barang dagangan.

2. Pendahuluan

Dalam pendahuluan PSAK No.14 memuat tentang tujuan pernyataan, ruang lingkup pernyataan dan definisi persediaan. Pendahuluan ini terdiri dari paragraf 1 sampai dengan paragraf 4 .

3. Tujuan

Tujuan pernyataan adalah untuk merumuskan perlakuan akuntansi untuk persediaan menurut sistem biaya historis. Permasalahan pokok dalam akuntansi persediaan adalah jumlah biaya yang harus diakui sebagai aktiva dan konversi selanjutnya sampai pendapatan yang bersangkutan diakui.

4. Ruang Lingkup

Dalam paragraf 1 PSAK No.14 mengatakan bahwa pernyataan ini harus diaplikasikan dalam penyusunan laporan keuangan dalam konteks sistem biaya historis tentang akuntansi persediaan selain:

a. Pekerjaan dalam proses yang timbul dalam kontrak kontruksi,

b. Instrumen keuangan, dan 
c. Persediaan yang dimiliki oleh persediaan yaitu sistem perpetual dan produsen peternakan, produk sistem periodik.

pertanian dan kehutanan, dan hasil tambang sepanjang persediaan tersebut dinilai berdasarkan nilai realisasi bersih sesuai dengan kelaziman praktek yang berlaku dalam industri tertentu.

Pernyataan Standar Akuntansi Keuangan (PSAK) No.14 Tahun 2014 adalah standar yang harus diikuti dalam pencatatan dan pelaporan akuntansi di Indonesia dan merupakan aturan yang harus ditaati oleh para akuntan agar pelaporan akuntansi di Indonesia ini menjadi lebih efektif.

\section{Akuntansi Persediaan Berdasarkan}

\section{PSAK No.14 Tahun 2014}

\section{Sistem Pencatatan Persediaan}

Sistem akuntansi yang akurat dan catatan yang up to date merupakan hal yang sangat penting. Penjualan dan pelanggan bisa hilang jika pesanan mereka tidak sesuai dengan model, kualitas dan kuantitas yang diinginkan. Oleh karena itu perusahaan harus selalu memonitor tingkat persediaan secara seksama dan membatasi biaya pembiayaan akibat penimbunan persediaan. Perusahaan menggunakan satu dari dua jenis sistem pencatatan
a. Metode Persediaan Perpetual (Perpetual Inventory Method)

Menurut Baridwan (2005:160) pengertian metode persediaan perpetual adalahpencatatan perpetual yaitu pencatatan atas transaksi persediaan yang dilaksanakan setiap waktu baik terhadap pemasukan maupun terhadap pengeluaran persediaan.

Metode pencatatan ini dibantu dengan buku pembantu persediaan barang dagangan dengan membuat kartu persediaan barang (stock card). Setiap jenis barang dibuatkan kartu persediaan dan didalam pembukuan dibuatkan rekening pembantu persediaan.Rincian dalam buku pembantu bisa diawasi dari rekening kontrol persediaan barang dalam buku besar. Rekening yang digunakan untuk mencatat persediaan ini terdiri dari beberapa kolom yang dapat dipakai untuk mencatat pembelian, penjualan, dan saldo persediaan. Setiap perubahan dalam persediaan diikuti dengan pencatatan dalam rekening persediaan sehingga jumlah persediaan sewaktu-waktu dapat diketahui dengan melihat kolom saldo dalam rekening persediaan. 
b. Metode Persediaan Periodik (Periodical Inventory Method)

Dalam metode periodik/fisik mengharuskan adanya perhitungan barang yang masih ada pada tanggal penyusunan laporan keuangan. Perhitungan persediaan (stock opname) ini diperlukan untuk mengetahui berapa jumlah barang yang masih ada dan kemudian diperhitungkan harga pokoknya. Dalam metode ini mutasi persediaan barang tidak diikuti dalam buku-buku, setiap pembelian barang dicatat dalam rekening pembelian. Karena tidak ada catatan mutasi persediaan barang maka harga pokok penjualan tidak dapat diketahuisewaktuwaktu.

Hamizar dkk (2009;92), menyatakan bahwa sistem pencatatan secara fisik/periodik (physical/periodic inventory system) sistem ini tidak secara langsung berkaitan dengan barang dagang yang bersangkutan. Misalnya bila terjadi pembelian barang dagangan akan dicatat pada rekening khusus yaitu pembelian dan penjualan barang dagangan dicatat pada rekening penjualan.

Menurut Suhayati dkk (2009;226), menjelaskan sistem pencatatan fisik/periodik (physical/periodic inventory system) merupakan pencatatan persediaan dimana:

1) Mutasi persediaan tidak menggunakan buku besar (inventory) melainkan memakai perkiraan purchases, purchases return, sales, sales return dan sebagainya,

2) Tidak memakai kartu persediaan,dan

3) Kalkulasi biaya persediaan dengan menetapkan persediaan akhir terlebih dahulu melalui perhitungan secara fisik selanjutnya dihitung cost of good sold.

2. Metode Penilaian Persediaan

Metode penilaian persediaan barang adalah menentukan nilai persediaan yang dicantumkan dalam neraca. Persediaan akhir bisa dihitung harga pokoknya dengan menggunakan beberapa cara penentuan harga pokok persediaan akhir, tetapi nilai ini tidak selalu nampak dalam neraca tergantung kepada metode penilaian yang dipakai. Untuk penentuan hasil usaha selama periode tertentu, maka persediaan memegang peranan yang sangat penting. Hal ini terutama disebabkan karena jumlah barang yang dibeli/produksi dalam periode yang sama.

Stice dkk (2009;667), menyatakan bahwa ada beberapa macam metode 
penilaian persediaan yang secara umum sering digunakan dalam penilaian persediaan yaitumetode ratarata(Average), metode FIFO (masuk pertama keluar pertama),dan metode LIFO (masuk terakhir keluar pertama).

Menurut Martini dkk (2012;251), menyatakan bahwa terdapat tiga alternatif yang dapat dipertimbangkan oleh suatu entitas terkait dengan asumsi arus biaya, yaitu :

a. Metode indentifikasi khusus,

b. Masuk pertama keluar pertama(FIFO), dan

c. Rata-rata tertimbang.

Hamizar dkk (2009;97), menyatakan bahwa pencatatan persediaan dengan sistem perpetual, setiap terjadi transaksi penjualan barang dagang diadakan perhitungan dan pencatatan harga pokok penjualan. Penilaian persediaan akhir dengan sistem perpetual dapat dilakukan dengan metode sebagai berikut:

a. Metode FIFO(First In First Out)

Metode FIFO (First In First Out)mengasumsikan bahwa barangbarang yang digunakan (dikeluarkan) sesuai urutan pembeliannya. Dengan kata lain, metode ini mengasumsikan bahwa barang yang pertama dibeli adalah barang yang pertama digunakan (dikeluarkan).
Oleh karena itu, persediaan yang tersisa merupakan barang yang dibeli paling terakhir.

b. Metode LIFO (Last In Last Out)

Metode LIFO (Last In Last Out)adalah metode penilaian persediaan dimana harga perolehan barang yang terakhir kali dibeli akan menjadi harga perolehan yang pertama kali digunakan. Metode LIFO (Last in first out), mengamsusikan bahwa barang yang trakhir dibeli harus dijual atau dikeluarkan terlebih dahulu. Bila penjualan (pengeluaran) barang yang terakhir melebihi jumlah pembelian barang dagang yang terakhir, maka diambilkan pada pembelian sebelumnya. Metode ini merupakan kebalikan dari metode FIFO (First in first out)

c. Metode Rata-Rata (Average)

Dalam metode ini, barang-barang yang dikeluarkan akan dibebankan harga pokok pada akhir periode, karena harga pokok rata-rata baru dihitung pada saat akhir periode, akibatnya jurnal untuk mencatat berkurangnya persediaan barang juga dibuat pada akhir periode. Apabila harga pokok rata-rata setiap saat sering kali terjadi pembelian barang, maka dalam satu periode akan terdapat beberapa harga pokok rata-rata. 
3. Pengukuran Biaya Persediaan

Persediaan harus diukur berdasarkan biaya atau nilai realisasi neto, mana yang lebih rendah. Biaya persediaan meliputi semua biaya pembelian, biaya konversi, dan biaya lain yang timbul sampai persediaan berada dalam kondisi dan lokasi saat ini. Sedangkan nilai realisasi neto adalah estimasi harga jual dalam kegiatan usaha biasa dikurangi estimasi biaya penyelesaian dan astimasi biaya yang diperlukan untuk membuat penjualan. Unsur biaya persediaan meliputi :

a. Biaya pembelian

Biaya pembelian persediaan meliputi harga beli, bea impor, pajak lainnya (kecuali yang kemudian dapat ditagih kembali oleh entitas kepada otoritas pajak), biaya pengangkutan, biaya penanganan, dan biaya lainnya yang secara langsung dapat diatribusikan pada perolehan barang jadi, bahan dan jasa, Diskon dagang, rabat dan hal lain yang serupa dikurangkan dalam menentukan biaya pembelian.

b. Biaya Konversi

Biaya konversi persediaan meliputi biaya yang secara langsung terkait dengan unit yang diproduksi, misalnya biaya tenaga kerja langsung. Termasuk juga alokasi sistematis overhead produksi tetap dan variabel yang timbul dalam mengonversi bahan menjadi barang jadi. Overhead produksi tetap adalah biaya produksi tidak langsung yang relatif konstan, tanpa memperhatikan volume produksi yang dihasilkan, seperti penyusutan dan pemeliharaan bangunan dan peralatan pabrik, dan biaya manajemen dan administrasi pabrik. Overhead produksi variabel adalah biaya produksi tidak langsung yang berubah secara langsung, atau hampir secara langsung, mengikuti perubahan volume produksi, seperti bahan tidak langsung dan biaya tenaga kerja tidak langsung.

c. Biaya Lain

Biaya lain hanya dibebankan sebagai biaya persediaan sepanjang biaya tersebut timbul agar persediaan berada dalam kondisi dan lokasi saat ini.

Menurut Baridwan (2005;161), adapun faktor-faktor penting yang harus diperhatikan dalam persediaan barang yaitu sebagai berikut:

a. Faktor persediaan bahan baku volume yang dibutuhkan untuk melindungi jalannya perusahaan terhadap gangguan kehabisan persediaan mengakibatkan produksi terganggu.
1) Volume produksi yang direncanakan sangat tergantung 
pada volume penjualan yang direncanakan,

2) Besarnya pembelian bahan baku setiap kali pembelian mendapatkan biaya pembelian yang minimal,

3) Estimasi fluktuasi harga bahan baku diwaktu yang akan dating,

4) Peraturan pemerintah yang menyangkut persediaan material/bahan baku,

5) Harga pembelian bahan baku, dan

6) Tingkat kecepatan bahan baku menjadi rusak atau turun kualitasnya.

b. Faktor persediaan pengamanan.

1) Risiko kehabisan persediaan, dan

2) Hubungan antara biaya penyimpanan di gudang disatu pihak dengan biaya-biaya ekstra yang harus dikeluarkan sebagai akibat dari kehabisan persediaan dilain pihak.

c. Faktor biaya persediaan.

1) Carrying cost, yaitu biaya-biaya yang meningkat dengan bertambahnya tingkat investasi dalam aktiva lancar, dan

2) Shortage cost, yaitu biaya-biaya yang menurun dengan bertambahnya tingkat investasi dalam aktiva lancar. d. Biaya persediaan barang (Inventory cost).

Biaya yang berkaitan dengan pemilik barang dapat dibedakan ke dalam :

1) Holding atau Carrying cost, yaitu biaya yang dikeluarkan karena memelihara atau menyimpan barang, atau opportunity cost karena melakukan investasi dalam bentuk barang dan bukan investasi lainnya,

2) Ordering cost, yaitu biaya yang dikeluarkan untuk memesan barang dari supplier untuk mengganti barang yang telah dijual, dan

3) Stock out cost, yaitu biaya yang timbul karena kehabisan barang pada saat diperlukan.

Sejauh mana permintaan barang oleh pembeli dapat diketahui jika permintaan barang dapat diketahui, maka perusahaan dapat menentukan beberapa kebutuhan barang dalam suatu periode.

\section{Pengakuan Sebagai Beban}

Terdapat dua pendekatan pengakuan beban persediaan, yaitu pendekatan aset dan pendekatan beban. Pendekatan aset digunakan untukpersediaan-persediaan yang nilainya 
material dan maksud penggunaannya untuk selama satu periode dan atau untuk maksud berjaga-jaga. Sedangkan pendekatan beban dapat digunakan untuk persediaan-persediaan yang nilainya relative tidak material dan maksud penggunaannya untuk waktu yang segera/tidak dimaksudkan untuk sepanjang satu periode.

Jika persediaan dijual, maka jumlah tercatat persediaan tersebut diakui sebagai beban pada periode diakuinya pendapatan atas penjualan tersebut. Setiap penurunan nilai persediaan di bawah biaya perolehan menjadi nilai realisasi neto dan seluruh kerugian persediaan diakui sebagai beban pada periode terjadinya penurunan atau kerugian tersebut. Setiap pemulihan kembali penurunan nilai persediaan karena peningkatan kembali nilai realisasi neto. Diakui sebagai pengurangan terhadap jumlah beban persediaan pada periode terjadinya pemulihan tersebut. Beberapa persediaan dapat dialokasikan ke pos aset lainnya.

Jurnal pengakuan beban persediaan Harga pokok penjualan $\mathrm{Rp} \quad \mathrm{xxx}$ Persediaan barang dagang
5. Pengungkapan Dalam Laporan Keuangan

Tujuan perusahaan dalam suatu perekonomian yang bersaing adalah memperoleh laba maksimal sesuai dengan pertumbuhan perusahaan dalam jangka panjang. Laporan keuangan yang ada di perusahaan merupakan sumber informasi yang berguna untuk pengambilan keputusan ekonomi.

Tujuan utama laporan keuangan menurut Ikatan Akuntan Indonesia (2009:3), adalah menyediakan informasi yang menyangkut posisi keuangan, kinerja, serta perubahan posisi keuangan suatu perusahaan yang bermanfaat bagi sejumlah besar pengguna dalam pengambilan keputusan ekonomi.Untuk dapat menyajikan sebuah laporan keuangan yang layak dan wajar, salah satu unsur yang sangat berpengaruh padalaporan keuangan adalah sistem pencatatan dan metode penilaian persediaan yang tepat dan benar. Dengan asumsi, nilai harga pokok dari persediaan barang akanmempengaruhi kelayakan laporan laba rugi yang disajikan oleh pihak perusahaan. 


\section{METODE PENELITIAN}

\section{Jenis Dan Sumber Data}

1. Jenis Data

Jenis data yang digunakan dalam melakukan penelitian adalah :

a. Data Kualitatif yaitu data yang diperbolehkan perusahaan dalam bentuk informasi, baik secara lisan maupun secara tertulis. Seperti data yang berupa penjelasan atau pernyataan yang tidak berbentuk angka tetapi merupakan sebuah sejarah singkat perusahaan.

b. Data Kuantitatif yaitu data yang diperbolehkan dari pihak perusahaan dalam bentuk angka-angka yang dapat dihitung. Data tersebut biasanya diperoleh dari laporan keuangan dan laporan persediaan perusahaan.

\section{Sumber Data}

Sumber data yang digunakan untuk melakukan penelitian adalah :

a. Data Primer

Pengumpulan data yang dilakukan dengan mengadakan wawancara baik secara langsung maupun secara tidak langsung dengan direktur utama perusahaan mengenai kebijakan akuntansi keuangan,persediaandan laporan keuangan dalam perusahaan. b. Data Sekunder

Pengumpulan data yang yang didapat secara tidak langsung dari perusahaan yang bersangkutan, seperti laporan keuangan dan laporan persediaan perusahaan selama periode tertentu serta data lain yang berkaitan langsung dengan penelitian yang bersumber dari Pernyataan Standar Akuntansi Keuangan(PSAK) No.14 Tahun 2014dan perpustakaan.

\section{Metode Pengumpulan Data}

Sehubungan dengan hal tersebut diatas, maka peneliti mengadakan penelitian dengan mengumpulkan data sebagai berikut :

1. Penelitian pustaka (Library research), yaitu penelitian dari berbagai pustaka atau mempelajari buku-buku literatur lainnya yang erat hubungannya dalampembahasan penelitian ini.

2. Penelitian lapangan (Field Research), yaitu metode pengumpulan data yang langsung pada objeknya,untuk mengumpulkan data yang benarbenar objektif melalui pendekatan sebagai berikut :

a. Interview yaitu teknik yang dilakukan dengan jalan mengadakan wawancara langsung dengan pihak perusahaan yang 
terkait langsung dalam pembahasan penelitian ini.

b. Dokumentasi yaitu teknik mengumpulkan data berupaberupa catatan, buku, dan formulirformulir yang digunakan dalam penelitian ini.

\section{Metode Analisis}

Metode analisis yang digunakan dalam penelitian ini adalahmetode deskriptif komparatif yaitu menjelaskan dan membandingkan akuntansi persediaan pada CV. Anugrah Djam Ritel dengan akuntansi persediaan PSAK No.14 Tahun 2014, terdiri dari pencatatan, penilaian, pengukuran, pengakuan, dan pengungkapan.

\section{HASIL PENELITIAN DAN}

PEMBAHASAN

\section{Akuntansi Persediaan Pada CV.}

\section{Anugrah Djam Ritel}

Sebagai perusahaan dagang, CV. Anugrah Djam Ritel memerlukan barang dagangan untuk dijual kembail,untuk memenuhi barang dagangan tersebut perusahaan melakukan kerjasama dengan beberapa supplier. Adapun peraturan atau kebijakan yang ditetapkan oleh perusahaan dalam kegiatan pengadaan barang dagangan adalah sebagai berikut :
1. Pengadaan persediaan dilakukan oleh bagian gudang,

2. Pengadaan persediaan dilakukan sesuai keputusan yang telah ditetapkan perusahaan,

3. Dalam kontrak kerjasama, pihak perusahaan yang menanggung transportasi dari gudang supplier ke gudang perusahaan,

4. Pengecekan barang dagangan di toko dilakukan setiap hari,

5. Setiap hari dilakukan penambahan barang dagangan dari gudang ke toko, agar toko tetap penuh,

6. Setiap aktivitas transaksi harus ada otoritas dari orang yang berwenang, jika tidak maka dianggap tidak sah,

7. Setiap catatan transaksi dibuat dengan komputer,

8. Pembelian dilakukan dengan melihat pertimbangan kualitas barang, ketepatan waktu pengiriman barang dan pertimbangan harga yang dapat bersaing dengan swalayan sejenis,

9. Jika ada produk yang tidak laku, akan dihilangkan dari toko dan diganti dengan produk lain yang kemungkinan laku jika dijual, dan

10. Sistem pencatatan perusahaan menggunakan metode perpetual yaitu setiap penjualan akan langsung diketahui harga pokok penjualannya. 
Dalam metode ini perusahaan tidak mengenal akun pembelian dalam pencatatannya. Namun akun pembelian diganti dengan akun persediaan barang dagang. Dalam metode persediaan perpetual, setiap pembelian barang dagangan dari pemasok akan dicatat oleh perusahaan dengan cara mendebet persediaan barang dagang dan mengkredit akun kas jika transaksi tersebut tunai atau hutang dagang jika transaksi tersebut merupakan transaksi kredit.

Persediaan barang dagangan pada umumnya diperoleh melalui kegiatan pembelian yaitu pengadaan barang dagangan yang dipicu dari adanya permintaan barang dagangan dari gudang apabila barang dagangan yang tersedia tinggal sedikit lagi.

Adapun prosedur pengadaan (pembelian) barang dagangan (persediaan) yang dilakukan oleh perusahaan, yaitu:

a. Bagian gudang memeriksa stok barang di komputer setelah dikurangi permintaan toko untuk pengiriman barang,

b. Bagian gudang membuat purchase order melalui komputer sebanyak 2 rangkap, c. Bagian gudang meminta otoritas purchase order kepada kepala bagian gudang,

d. Purchase order lembar 1 yang sudah diotorisasi dikirim kepada supplier sedangkan lembar ke 2 diserahkan kepada bagian akuntansi,

e. Supplier menerima purchase order, kemudian membuat faktur 3 rangkap berdasarkan purchase order,

f. Faktur 3 rangkap dan purchase order tersebut kemudian dikirim ke gudang perusahaan,

g. Bagian gudang perusahaan menerima faktur 3 rangkap beserta purchase order dan barang,

h. Kemudian bagian gudang memeriksa purchase order, faktur dan barang,

i. Jika barang telah sesuai dengan purchase order dan faktur maka akan diotorisasi oleh bagian gudang perusahaan, namun jika barang tidak sesuai dengan purchase order maka akan dibuatkan bukti return atas barang tersebut, dan

j. Atas barang yang telah di periksa dan telah diotorisasi, maka supplier diberikan 1 lembar purchase order, sedangkan faktur 3 lembar dibuat sebagai bukti masuk barang, 1 lembar dipegang oleh gudang dan 2 lembar 
diberikan kepada bagian akuntansi untuk dibuatkan jurnalnya.

Data mengenai persediaan yang penulis sajikan adalah data persediaan tahun 2015 hanya menggunakansalah satu produk sebagai sampel barang dagangan yaitu Aqua dengan jenis Aqua $1.500 \mathrm{ml}$ dan Aqua $600 \mathrm{ml}$, sebagai acuan dalam melakukan pencatatan dan penilaian serta penyajian dan pelaporan keuangan (laporan laba rugi dan neraca).

\section{Pencatatan}

Berdasarkan hasil penelitian diatas dalam pemilihan metode yang dipakai untuk pencatatan persediaan, $\mathrm{CV}$. Anugrah Djam Ritelmenggunakan metode mutasi persediaan ataumetode perpetual, dimana pemasukan (pembelian) maupun penjualanbarang dicatat langsung kedalam perkiraan persediaan pada saat itu juga. Pencatatan transaksi pada perusahaan dilakukan dengan sistem komputerisasi dimana perusahaan menggunakan pembukuan yang telah didesain sedemikian rupa untuk memudahkan dalam pencatatan setiap transaksi dalam aktivitas perusahaan. Pemilihan menggunakan metode perpetual yang dilakukan oleh perusahaan dengan alasan, apabila sewaktuwaktuingin mengetahui jumlah persediaan yang siap digunakan dalamproses produksi, maka hal itu dapat diketahui dengan melihat bukugudang juga karena jenis persediaan perusahaan yang sangat banyak atau beragam.

a. Pembelian Persediaan Barang

Dalam transaksi pembelian barang dagang, CV. Anugrah Djam Ritel melakukan dua sistem pembelian yaitu pembelian secara tunai dan pembelian secara kredit. Untuk mencatat pembelian persediaan barang dagang secara tunai perusahaan mencatatnya dalam jurnal sebagai berikut :

Persediaan barang dagang

$$
\text { Rp.148.500.000 }
$$

Kas

$$
\text { Rp.148.500.000 }
$$

Sedangkan untuk mencatat pembelian persediaan barang dagangsecara kredit jurnalnya adalah :

Persediaan barang dagang

Rp.198.000.000

Utang dagang

Rp.198.000.000

\section{b. Penjualan Barang Dagang}

Produk yang dijual CV. Anugrah Djam Ritel mempunyai dua sistem pembayaran yaitu secara tunai dan kredit. Untuk pembayaran secara kredit, 
perusahaan mempunyai beberapa term of payments yaitu 7 hari, 10 hari, 20 hari dan 30 hari dimulai saat invoice dicetak ataupun saat invoice diterima pelanggan. Untuk penjualan secara tunai maka jurnalnya adalah sebagai berikut :

Kas

$$
\text { Rp.21.600.000 }
$$

Penjualan

$$
\text { Rp.21.600.000 }
$$

Jika terjadi penjualan secara kredit, maka perusahaan akan mencatat jurnal sebagai berikut :

Piutang dagang

$$
\text { Rp.27.000.000 }
$$

Penjualan

$$
\text { Rp.27.000.000 }
$$

\section{c. Biaya Angkut}

Dalam mencatat biaya angkut pembelian maka jurnalnya sebagai berikut :

Biaya angkut pembelian

$$
\text { Rp. } 10.300 .000
$$

Kas

$$
\text { Rp. } 10.300 .000
$$

\section{Penilaian}

Metode penilaian persediaan yang digunakan oleh CV. Anugrah Djam Ritelmenggunakan metode FIFO (First In
First Out). Pemilihan metodeini cukup baik karena barang yang masuk gudang awal akan dikeluarkan lebih dulu, hal ini dapat mengurangi resiko adanya penimbunan barang yang rusak/cacatkarena terlalu lama dalam penyimpanan. Dalam hal ini perusahaan telah sesuai dengan PSAK No.14 dimana FIFO (First In First Out) barang yang pertama kali masuk adalah barang yang pertama kali keluar atau dijual. Sehingga barang yang masih ada dalam gudang adalah termasuk persediaan barang yang terakhir masuk.

\section{Pengukuran}

Dalam menentukan biaya-biaya dalam persediaan, penulis tidak membaginya secara umum maupun khusus, hal ini dikarenakan biaya-biaya yang terdapat dalam menghasilkan produk hampir seluruhnya sama mencakup seluruh produk barang dagangan yang ada pada CV. Anugrah Djam Ritel. Dalam menetapkan haga perolehan persediaan perusahaan hanya menghitung harga beli dan biaya-biaya yang sehubungan dengan pembelian barang dagangan sebagai haga perolehan persediaan. 
Tabel 1 Persentase Ratio Metode Eceran

\begin{tabular}{|l|c|c|}
\hline \multicolumn{1}{|c|}{ Keterangan } & Harga Perolehan & Harga Eceran \\
\hline Persediaan Awal & Rp.330.000.000 & Rp.404.124.000 \\
\hline Pembelian & Rp.446.600.000 & Rp.531.644.600 \\
\hline Biaya Angkut & Rp.85.200.000 & Rp.85.200.000 \\
\hline Barang Siap Dijual & Rp.861.800.000 & Rp.1.020.968.600 \\
\hline
\end{tabular}

Sumber : CV. Anugrah Djam Ritel, 2015

Ratio harga perolehan terhadap harga eceran :

$$
\text { Rp.861.800.000 : Rp.1.020.968.600 x 100\% = 84\% }
$$

Persediaan akhir 31 Desember 2015 dengan metode eceran :

$$
\text { Rp.1.020.968.600 - Rp.876.250.000 = Rp.144.718.600 }
$$

Persediaan akhir menurut harga perolehan :

$$
\text { Rp.144.718.600 x 84\% = Rp.121.563.624 }
$$

Metode eceran adalah salah satu teknik untuk mengukur biaya pada persediaan. CV. Anugrah Djam Ritel menggunakan metode eceran dalam transaksi penjualan, selain melihat kondisivolume penjualan yang relatif tinggi juga untuk memperoleh pendapatan yang lebih besar.

\section{Pengakuan}

CV. Anugrah Djam Ritel menerapkan pengakuan sebagai beban pada saat terjadi penjualan barang yang mendebet akun harga pokok penjualan dan mengkredit akun persediaan sehingga akun persediaan akan menunjukkan harga pokok dari persediaan yang ada di gudang, dan dicatat dalam jurnal sebagai berikut :

Harga pokok penjualan Rp.27.000.000

Persediaan barang dagang

$$
\text { Rp.27.000.000 }
$$

\section{Pengungkapan}

Hal-hal yang dipandang perlu untuk diungkapkan dalam laporan keuangan sehubungan dengan persediaan meliputi :

a. Kebijakan akuntansi yang digunakan dalam pengukuran persediaan,

b. Penjelasan lebih lanjut persediaan seperti barang atau perlengkapan yang digunakan, barang atau 
perlengkapan yang digunakan dalam proses produksi, barang yang disimpan untuk dijual, dan barang yang masih dalam proses, dan

c. Kondisi persediaan. Persediaan dengan kondisi rusak atau usang tidakdilaporkan dalam neraca, tetapi diungkapkan dalam catatan atas laporan keuangan.

Pengungkapan persediaan barang dagang yang diterapkan pada CV. Anugrah Djam Ritel, dapat dilihat dari laporan berikut ini :

Tabel 2 Laporan Neraca

CV. Anugrah Djam Ritel

Neraca

Per 31 Desember 2015

\section{Aktiva}

Aktiva Lancar :

Kas

Rp. $\quad 248.000 .000$

Bank

Rp. 1.095 .000 .000

Piutang Dagang

Rp. $\quad 212.100 .000$

Persediaan

Rp. $\quad 121.563 .624$

Total Aktiva Lancar

Rp. 1.676 .663 .624

Sumber : CV. Anugrah Djam Ritel, 2015

Tabel 3 Laporan Laba Rugi

\begin{tabular}{|c|c|}
\hline & $\begin{array}{l}\text { CV. Anugrah Djam Ritel } \\
\text { Laporan Laba Rugi } \\
\text { Per 31 Desember 2015 }\end{array}$ \\
\hline Penjualan Bersih & Rp 876.250 .000 \\
\hline Persediaan Awal & $\mathrm{Rp} \quad 330.000 .000$ \\
\hline Pembelian & $\mathrm{Rp} \quad 446.600 .000$ \\
\hline Biaya Angkut Pembelian & $\underline{\mathrm{Rp}} \quad 85.200 .000$ \\
\hline Barang tersedia untuk dijual & $\mathrm{Rp} \quad 861.800 .000$ \\
\hline Persediaan Akhir & $(\mathrm{Rp} \mathrm{121.563.624)}$ \\
\hline Harga Pokok Penjualan & $\underline{(\operatorname{Rp~740.236.376)~}}$ \\
\hline Laba Kotor & Rp 136.013 .624 \\
\hline Beban Operasional & $(\mathrm{Rp} \quad 10.650 .000)$ \\
\hline $\begin{array}{l}\text { Laba Sebelum Pajak } \\
\text { Pajak Penghasilan }\end{array}$ & $\begin{array}{ll}\mathrm{Rp} & 125.363 .624 \\
& \underline{\operatorname{Rp~15.670.453)}}\end{array}$ \\
\hline Laba Bersih Setelah Pajak & Rp 109.693.171 \\
\hline
\end{tabular}

Sumber : CV. Anugrah Djam Ritel, 2015 
Penyajian persediaan dalam laporan keuangan pada CV. Anugrah Djam Ritel, dimana persediaan akhir dapat dilihat dalam neraca dalam akun aset lancar dan harga pokok penjualan pada laporan laba rugi. Dalam perhitungan laba rugi, nilai persediaan (awal dan akhir) sangat mempengaruhi besarnya Harga Pokok Penjualan (HPP). Dalam pelaporan keuangan, persediaan merupakan hal yang sangat penting karena baik laporan laba rugi maupun neraca tidak akan dapat disusun tanpa mengetahui nilai persediaan. Kesalahan yang sering timbul dalam penilaian persediaan akan langsung berakibat dalam laporan laba rugi maupun neraca.

\section{Akuntansi Persediaan Menurut PSAK} No.14 Tahun 2014

Pernyataan Standar Akuntansi Keuangan (PSAK)No.14 Tahun 2014 adalah standar yang harus diikuti dalam pencatatan dan pelaporan akuntansi di Indonesia. PSAK No.14 Tahun 2014 ini merupakan aturan-aturan yang harus ditaati oleh para akuntan agar pelaporan akuntansi di Indonesia ini menjadi lebih efektif.

\section{Pencatatan}

Sistem pencatatan persediaan denganmetode perpetual merupakan salah satu metode yang telah sesuai dengan PSAK No.14 Tahun 2014, dimana pada saat transaksi pembelian terjadi dicatat dengan mendebet perkiraan persediaan barang dagangan dan mengkredit kas atau hutang dagang pada saat terjadi penjualan, harga pokok barang yang terjual dicatat dengan harga pokok penjualan dan mengkredit perkiraan persediaan barang dagang.

a. Pembelian Persediaan Barang

Untuk mencatat pembelian persediaan barang dagang secara tunai perusahaan mencatatnya dalam jurnal sebagai berikut :

Persediaan barang dagang

$$
\text { Rp.148.500.000 }
$$

Kas

$$
\text { Rp.148.500.000 }
$$

Sedangkan untuk mencatat pembelian persediaan barang dagangsecara kredit jurnalnya adalah :

Persediaan barang dagang

$$
\text { Rp.198.000.000 }
$$

Utang dagang

$$
\text { Rp.198.000.000 }
$$


b. Penjualan Barang Dagang

Untuk penjualan secara tunai maka jurnalnya adalah sebagai berikut :

Kas

$$
\text { Rp.21.600.000 }
$$

Penjualan

$$
\text { Rp.21.600.000 }
$$

Jika terjadi penjualan secara kredit, maka perusahaan akan mencatat jurnal sebagai berikut :

Piutang dagang

$$
\text { Rp.27.000.000 }
$$

Penjualan

$$
\text { Rp.27.000.000 }
$$

\section{c. Biaya Angkut}

Dalam mencatat biaya angkut pembelian maka jurnalnya sebagai berikut :

Biaya angkut pembelian

$$
\text { Rp. } 10.300 .000
$$

Kas

$$
\text { Rp. } 10.300 .000
$$

\section{Penilaian}

Metode penilaian persediaan dengan menggunakan metode FIFO telah sesuai dengan PSAK No.14 Tahun 2014, barang yang masuk gudang awal akan dikeluarkanlebih dulu, hal ini dapat mengurangi resiko adanya barang yang rusakkarena terlalu lama dalam penyimpanan.

\section{Pengukuran}

Metode eceran adalah salah satu teknik untuk mengukur biaya pada persediaanyangmerupakan teknik pengukuran nilai persediaan sesuai dengan PSAK No.14 Tahun 2014, Langkah-langkah untuk menentukan nilai persediaan dalam metode eceran dapat diukur sebagai berikut:

a. Menetapkan harga eceran/harga jual,

b. Menetapkan rasio/perbandingan antara harga perolehan barang yang tersedia untuk dijual dengan harga eceran,

c. Menetapkan persediaan akhir menurut harga eceran, yaitu barang yang tersedia untuk dijual menurut harga eceran dikurangi dengan penjualan, dan

d. Menetapkan nilai persediaan berdasarkan persentase ratio harga perolehan terhadap harga eceran. 
Tabel 4 Persentase Ratio Metode Eceran

\begin{tabular}{|l|c|c|}
\hline \multicolumn{1}{|c|}{ Keterangan } & Harga Perolehan & Harga Eceran \\
\hline Persediaan Awal & Rp.330.000.000 & Rp.404.124.000 \\
\hline Pembelian & Rp.446.600.000 & Rp.531.644.600 \\
\hline Biaya Angkut & Rp.85.200.000 & Rp.85.200.000 \\
\hline Barang Siap Dijual & Rp.861.800.000 & Rp.1.020.968.600 \\
\hline
\end{tabular}

Sumber : Data diolah, 2015

Ratio harga perolehan terhadap harga eceran :

$$
\text { Rp.861.800.000 : Rp.1.020.968.600 x 100\% = 84\% }
$$

Persediaan akhir 31 Desember 2015 dengan metode eceran :

$$
\text { Rp.1.020.968.600 - Rp.876.250.000 = Rp.144.718.600 }
$$

Persediaan akhir menurut harga perolehan :

$$
\text { Rp.144.718.600 x 84\%=Rp.121.563.624 }
$$

Seperti yang dijelaskan bahwa dalam PSAK No.14 Tahun 2014, bahwa biaya persediaan harus meliputi biaya pembelian, biaya konversi dan biaya yang timbul sampai persediaan berada dalam kondisi dan tempat yang siap dijual atau dipakai, terdiri dari :

a. Biaya pembelian, yang termasuk dalam biaya ini adalah segala biaya yang dikeluarkan sehubungan dengan aktivitas pembelian yaitu :
a) Harga pembelian produk
b) Biaya pengangkutan produk
c) Biaya penanganan
d) Biaya pajak

b. Biaya lain-lain, yang termasuk biaya lain-lain adalah biaya yang terjadi untuk mempersiapkan barang dagang yang diperoleh agar berada pada kondisi dan tempat yang baik dan siap dijual seperti :
a) Biaya penyimpanan
b) Biaya perawatan produk
c) Biaya Biaya penjualan produk
d) Biaya administrasi

\section{Pengakuan}

Dalam Pernyataan Standar Akuntansi Keuangan (PSAK) No.14 Tahun 2014, jika barang dalam persediaan dijual, maka nilai tercatat persediaan tersebut harus diakui sebagai beban pada periode diakuinya pendapatan atas penjualan tersebut yang dicatat dalam jurnal sebagai berikut : 
Harga pokok penjualan

$$
\text { Rp.27.000.000 }
$$

Persediaan barang dagang

$$
\text { Rp.27.000.000 }
$$

10. Pengungkapan

$$
\text { Pengungkapan dalam laporan }
$$
keuangan sesuai dengan PSAK No.14 Tahun 2014, dimana persediaan di neraca sebagai harta lancar berada di kelompok passiva dan di laporan laba rugi dalam komponen Harga Pokok Penjualan (HPP) yang disusun perbulan dan laporan tahunan disusun yang menghasilkan laporan keuangan tahunan.Pengungkapan persediaan barang dagang yang diterapkan sebagai berikut :

Tabel 5 Laporan Neraca

\section{Anugrah Djam Ritel}

Neraca

Per 31 Desember 2015

\begin{tabular}{ll}
\hline Aktiva & \\
Aktiva Lancar : & \\
Kas & Rp. 248.000 .000 \\
Bank & Rp. 1.095 .000 .000 \\
Piutang Dagang & Rp. 212.100 .000 \\
Persediaan $\quad$ Rp. 121.563 .624 \\
$\quad$ Total Aktiva Lancar & Rp.1.676.663.624 \\
\hline
\end{tabular}

\begin{tabular}{|c|c|}
\hline & $\begin{array}{l}\text { CV. Anugrah Djam Ritel } \\
\text { Laporan Laba Rugi } \\
\text { Per 31 Desember 2015 }\end{array}$ \\
\hline Penjualan Bersih & $\operatorname{Rp} 876.250 .000$ \\
\hline $\begin{array}{l}\text { Persediaan Awal } \\
\text { Pembelian } \\
\text { Biaya Angkut Pembelian } \\
\text { Barang tersedia untuk dijual }\end{array}$ & $\begin{array}{lr}\mathrm{Rp} & 330.000 .000 \\
\mathrm{Rp} & 446.600 .000 \\
\mathrm{Rp} & 85.200 .000 \\
\mathrm{Rp} & 861.800 .000\end{array}$ \\
\hline $\begin{array}{l}\text { Persediaan Akhir } \\
\text { Harga Pokok Penjualan }\end{array}$ & $\begin{array}{l}(\mathrm{Rp} 121.563 .624) \\
(\mathrm{Rp} 740.236 .376)\end{array}$ \\
\hline $\begin{array}{l}\text { Laba Kotor } \\
\text { Beban Operasional }\end{array}$ & $\begin{array}{rr}\mathrm{Rp} & 136.013 .624 \\
(\mathrm{Rp} & 10.650 .000) \\
\end{array}$ \\
\hline $\begin{array}{l}\text { Laba Sebelum Pajak } \\
\text { Pajak Penghasilan }\end{array}$ & $\begin{array}{cc}\mathrm{Rp} & 125.363 .624 \\
(\mathrm{Rp} & 15.670 .453) \\
\end{array}$ \\
\hline Laba Bersih Setelah Pajak & 109.693 .171 \\
\hline
\end{tabular}

Sumber : Data diolah, 2015

Tabel 6 Laporan Laba Rugi

Sumber : Data diolah, 2015 
Penyajian persediaan dalam laporan keuangan sesuai dengan PSAK No.14, dimana persediaan akhir dapat dilihat dalam neraca dalam akun aset lancar dan harga pokok penjualan pada laporan laba rugi. Persediaan barang dagangan yang tercantum di neraca mencerminkan nilai barang dagangan yang ada pada tanggal neraca yang biasanya di akhir periode akuntansi.

\section{Perbandingan Akuntansi Persediaan} Perusahaan dengan PSAK No.14 tahun 2014

Berdasarkan perbandingan akuntansi persediaan di atas, dapat disimpulkan bahwa CV. Anugrah Djam Ritel dalam menjalankan akuntansi persediaan sesuai dengan akuntansi persediaan PSAK No.14 tahun 2014, hal ini dapat dilihat dari penjelasan sebagai berikut :

1. Pencatatan yang diterapkan pada CV. Anugrah Djam Ritel telah sesuai dengan akuntansi persediaan PSAK No.14 Tahun 2014 yaitu menggunakan metode perpetual, dimana pemasukan (pembelian) maupun penjualan barang dicatat langsung kedalam perkiraan persediaan pada saat itu juga,
2. Penilaian persediaan menggunakan metode FIFO (First In First Out), dimana pada metode FIFO barang yang pertama kali masuk adalah barang yang pertama kali keluar.Meskipun penilaian persediaannya hanya membebankan pada biaya pembelian tanpa adanya biaya penyimpanan yang sebenarnya diperlukan untuk menjaga kualitas produk yang disimpan di gudang,

3. CV. Anugrah Djam Ritel menerapkan metode eceran sebagai teknik pengukuran persediaan yang digunakan perusahaan, yang merupakan metode yang seringkali digunakan dalam industri eceran untuk menilai persediaan dalam jumlah besar item yang berubah dengan cepat dan memiliki marjin yang sama di mana tidak praktis untuk menggunakan metode penetapan biaya lainnya. Dalam hal ini perusahaaan telah sesuai dengan akuntansi persediaan PSAK No.14 Tahun 2014,

4. CV. Anugrah Djam Ritel menerapkan pengakuan sebagai beban pada saat terjadi penjualan barang dagang, sehingga akun persediaan akan menunjukkan harga pokok dari persediaan yang ada di gudang, dalam 
hal ini sesuai dengan akuntansi persediaan PSAK No.14 Taahun 2014, dan

5. Pengungkapan dalam laporan keuangan CV. Anugrah Djam Ritel disajikan dalam laporan keuangan neraca dan laba rugi yang telah sesuai dengan Standar Akuntansi Keuangan yang berlaku di Indonesia, yaitu PSAK No.14 Tahun 2014.

\section{KESIMPULAN DAN SARAN}

\section{Kesimpulan}

Berdasarkan hasil penelitian yang telah di kemukakan pada pembahasan sebelumnya, maka penulis menarik kesimpulan bahwa akuntansi persediaanyang diterapkan pada $\mathrm{CV}$. Anugrah Djam Ritel telah sesuai dengan akuntansi persediaan PSAK No.14 Tahun 2014. Hal ini dapat dilihat dari penjelasan dan perbandingan akuntansi persediaan yang terdiri dari pencatatan, penilaian, pengukuran, pengakuan, dan pengungkapan yang telah sesuai.

\section{Saran}

Berdasarkan kesimpulan, maka saran diharapkan CV. Anugrah Djam Ritelperlu menjaga laporan mengenai akuntansi persediaan berdasarkan standar akuntansi keuangan yang berlaku.

\section{DAFTAR PUSTAKA}

Baridwan. Zaki, 2005:Manajemen Persediaan. Ekonisia FE UI; Jakarta.

Firdaus. Dunia, 2005:Pengantar Akuntansi 2. Edisi revisi, Fakultas Ekonomi Universitas Indonesia; Jakarta.

Hamizar. dan Nuh Muhamad, 2009:Intermediate Accounting. Fajar; Jakarta.

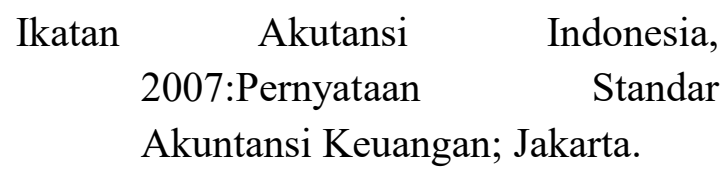

2009:Pernyataan Standar Akuntansi Keuangan.Salemba empat; Jakarta.

Keown. ArthurJ., Martin, John D., Petty, J William, 2010:Manajemen Keuangan: Prinsip dan Penerapan. Jilid 2. Edisi Kesepuluh. PT. Indeks; Jakarta.

Kieso. Donald, Jerry J, Weygand and Terry D, Warfield, 2008:Intermediate Accounting. Edisi 12 :by Erlangga.

Martini. Dwi, Sylvia Veronica Nps, Ratna Whardhani, Aria Farahmita dan Edward Tanujaya, 2012:Akuntansi Keuangan Menengah BerbasisPSAK, Buku 1.Salemba Empat; Jakarta. 
Reeve. Warren dan Duchac, 2009:Pengantar Akuntansi

Adaptasi di Indonesia. Salemba Empat; Jakarta.

Salim. Peter, 2009:Kamus Bahasa Indonesia Kontemporer. Graha Ilmu; Yogyakarta

Stice. dan Skousen, 2009:Akuntansi Intermediate. edisi keenam belas,Buku 1.Salemba Empat;Jakarta.

Suhayati. Ely, Dewi, Sri, Anggadini, 2009: Akuntansi keuangan. Graha ilmu; Yogyakarta.

Syafi'i. Syakur Ahmad, 2012:Akuntansi Keuangan Menengah Dalam Perspektif Lebih Luas.AV Publiser; Jakarta. 